\title{
HAEMOLYTIC DISEASE OF THE NEWBORN PIGLET
}

\author{
BY R. F. W. GOODWIN, D. H. HEARD, \\ B. H. G. HAYWARD* AND G. FULTON ROBERTS \\ Departments of Pathology and Veterinary Clinical Studies, University of Cambridge
}

(With 3 Figures in the Text)

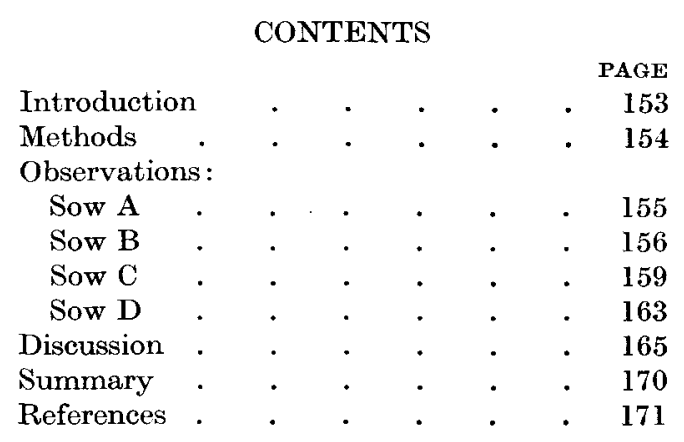

\section{INTRODUCTION}

Haemolytic disease of the newborn is an acute haemolytic anaemia acquired in some species as a result of maternal antibodies against red blood cell antigens gaining access to the circulation of the offspring possessing these antigens, either in utero or immediately after birth. It is not certainly known in many cases how the mother becomes immunized against foetal red cell antigens. In man the immunization may have been artificially induced, for example, by incompatible blood transfusion, and since the observations reported in this paper were made, it has been shown by Goodwin, Saison \& Coombs (1955) that iso-immunization of the sow against blood group antigens may result from the administration of crystal violet vaccine against swine fever. Similar observations in the horse suggested that equine abortion vaccine might be responsible for the appearance of haemagglutinating antibodies in mares (Doll, Richards, Wallace \& Bryans, 1952). The cases reported in this paper, though apparently occurring naturally, are best considered as comparable with those deliberately induced by artificial immunization (Bruner, Brown, Hull \& Kinkaid, 1949). The cases reported by Doll \& Brown (1954) also concerned a sow that had been vaccinated with crystal violet vaccine, but this point is not determined in the cases published by Szent Iványi \& Szabó (1953).

The first accounts of haemolytic disease in newborn piglets in this country are those of Buxton \& Brooksbank $(1953 a, b)$; four of the sows that they had observed farrowed subsequently at Cambridge, and these four litters were the subject of this investigation.

\section{* Deceased.}


In this paper the sows are labelled A, B, C and D (B and C are litter sisters) and the boar that served them is boar I. All five animals belong to pig blood group A. The four litters comprised forty-five piglets numbered consecutively (omitting 40) generally in accord with the birth order; the litter of sow A comprised piglets nos. 1-13, that of sow B those nos. 14-26, that of sow C nos. 27-39 and that of sow $D$ nos. 41-46. In addition, three normal newborn piglets were studied histologically.

The purpose of the investigation was to observe the clinical condition of haemolytic disease in newborn piglets, and correlate this with such haematological, serological and biochemical data as could be collected conveniently, and to observe the pathological changes in some of the animals that died. It was hoped that such a survey, though necessarily superficial in many respects, would indicate which aspects of this disease might profitably repay further study. The clinical condition of the litters showed four different grades of severity, the litter of sow A being the mildest and that of sow $\mathrm{C}$ the most severe.

\section{METHODS}

Blood samples. These were obtained from the sows by inserting a needle into an ear vein, and from the piglets by cutting off the end of the tail or by cutting the umbilical cord twice. In all cases the blood was allowed to drip freely. Blood samples were taken into dry sterile bottles, into acid-citrate-dextrose solution as used for human transfusion work, or into bottles containing dried heparin.

Milk samples. These were taken from the sow by hand-milking, generally during convenient 'let-down' periods.

Blood sugar estimations. Blood samples were deproteinized with barium hydroxide and zinc sulphate. The final blood filtrate was generally a $1 / 23$ dilution of whole blood. The sugar content was estimated with the reagent of Somogyi (1945), but with a modified procedure (Goodwin, unpublished). Sugar solutions of known strength (checked by polarimetry) were included as controls.

Serum bilirubin estimations. The method used was that of Patterson, Swale \& Maggs (1952).

Serological methods. Physiological saline solution, buffered with $0 \cdot 15 \mathrm{M}$ phosphate buffer, $\mathrm{pH} 7 \cdot 0$, was used as a diluent. For the antiglobulin tests a rabbit anti-pig serum absorbed with well-washed pig's red cells was used. Equal volumes of the antiglobulin serum, and a $2 \%$ suspension of four-times washed red cells were incubated together at $37^{\circ} \mathrm{C}$. for $1 \mathrm{hr}$. before the tests were read by the naked eye and microscopically. For the indirect antiglobulin test sensitization was allowed for $30 \mathrm{~min}$. at $37^{\circ} \mathrm{C}$. before the cells were washed three times and exposed to antiglobulin serum. Serial dilutions of pig sera were divided into two parts, the one being read as a direct agglutination test and the other treated as for the indirect antiglobulin test. Unless otherwise stated, the cells of boar I were used for titrations of the sows' and piglets' sera.

Haematological methods. For haemoglobin estimations $20 \mathrm{~mm} \cdot{ }^{3}$ of blood were taken into $4 \mathrm{ml}$. of $0.4 \%$ ammonia and read on a Unicam spectrophotometer at $545 \mathrm{~m} \mu$. Reticulocytes were estimated by the technique described in Wintrobe's 
Clinical Haematology. Nucleated cell counts were performed by the standard technique but crystal violet was omitted from the counting fluid. Leishman's stain was used for smears upon which differential counts were performed.

Histological methods. Fixatives used were formol saline, Heidenhain's Susa and formol-Zenker. Staining processes employed were haematoxylin and eosin, Perl's ferrocyanide method, Turnbull's ferricyanide method, Lison's Patent Blue, Laidlaw's reticulin stain, Lillie's Oil Red $O$ and Best's carmine.

\section{OBSERVATIONS}

\section{Sow $A$}

History and clinical observations. Sow A was $2 \frac{1}{2}$ years old at the time of study, and was said to have been vaccinated twice against swine fever, when 10 months old and 5 months before the present farrowing. It was reported that her first litter of three was successfully reared but her second of eleven had all died of jaundice; no further details of this litter are known. Her third litter of eight piglets was successfully reared. A different boar was responsible for each of these three litters and for the fourth which we describe.

Thirteen piglets were born in $6 \mathrm{hr}$. and $50 \mathrm{~min}$. on 28 May 1953, and cord blood samples were taken from each before it was allowed to suckle. Four piglets did not survive; no. 4 (which did not thrive) and no. 8 were slaughtered at $4 \frac{1}{2}$ and $2 \mathrm{hr}$. old respectively, the latter for histological study, and nos. 1 and 13 were found dead on the morning after birth looking as though they had been overlain by the sow. Of the remaining animals, nos. 2, 3 and 5-7 were selected for serial studies and nos. 9-12 were not at first investigated.

The animals that survived this experiment appeared healthy and no clinical evidence of disease was found. On the third day, however, it became evident that the piglets that were not being investigated (nos. 9-12) were thriving more than

Table 1

\begin{tabular}{ccccc} 
& Hb in g. \%, & Wt. in lb., & \multicolumn{2}{c}{ Blood sugar, $\mathrm{mg} . / 100 \mathrm{ml}}$. \\
Piglet no. & $\begin{array}{c}\text { 5th day } \\
\text { 5th day }\end{array}$ & 3rd day & 5 th day \\
2 & $6 \cdot 3$ & $2 \frac{3}{4}$ & 67 & 99 \\
3 & $6 \cdot 3$ & 3 & 37 & 101 \\
10 & $8 \cdot 1$ & $4 \frac{3}{4}$ & 114 & 117 \\
12 & $9 \cdot 2$ & 5 & 92 & 122
\end{tabular}

those under examination, presumably because their access to milk was less frequently interrupted by bleedings for testing samples. This impression is supported by the weights, haemoglobin and blood sugar levels on the fifth day of two animals being frequently tested (nos. 2 and 3 ) and two that were not being investigated (nos. 10 and 12) recorded in Table 1 ; since from the third day all the animals were removed from the sow when the test animals were bled, the disparity between the two groups on the fifth day is less marked in blood sugar levels than in weights. 
Serological findings. Ten days before delivery the sow's serum titre determined against the boar's cells was 16 by direct agglutination and 64 by the indirect antiglobulin sensitization test. The serum titres, determined 1,6 and 14 days after delivery, did not differ by more than one tube from these results. The milk titres were higher, being 128 by both methods in nearly all the samples taken during or within $50 \mathrm{hr}$. of farrowing.

The cord blood samples of all the piglets (except number 8 which was not examined) were tested at birth with rabbit anti-pig-globulin serum and were negative. After 9-10 hr. of suckling, samples from six of the piglets were examined again; no. 1 was negative and nos. 2, 3 and 5-7 were positive, though the strength of the agglutination varied between them. Samples from these last five piglets were tested after $20 \mathrm{hr}$. of suckling and all proved strongly positive.

Haematological findings. The haemoglobin levels of the three animals studied most fully (nos. 2, 3 and 6 ) fell by about one-third, that is to about $6 \frac{1}{2}-8 \frac{1}{2} \mathrm{~g}$., during the first $12 \mathrm{hr}$. The findings in one of these animals (no. 6), together with the two readings for no. 1, are given in Fig. 1. It was noticed that sensitized erythrocytes were autoagglutinated at room temperature which rendered total red cell counts unreliable; the difficulty was overcome when Hayem's diluting fluid was replaced by formalin-citrate mixture.

Histological findings. Piglet no. 8 was slaughtered when $2 \mathrm{hr}$. old and was regarded as a normal control for histological purposes. Piglet no. 5 was slaughtered at $56 \mathrm{hr}$. and examined forthwith. Piglet no. 13 was also examined post-mortem, though its time of death was not established, being between 8 and $16 \mathrm{hr}$. old. In the liver of nos. 5 and 13 glycogen vacuolation was marked and the Kupffer cells were prominent. There was no evidence of extramedullary haemopoiesis and no pigment deposition. The spleen of no. 5 was relatively bloodless, though the pulp was packed with cells and the lymphocytic cuffs were marked; extramedullary haemopoiesis was slight and predominantly myeloid. There was no evidence of erythrophagocytosis and no pigment was seen. The spleen of no. 13 differed only in displaying more erythropoiesis, being about equivalent to that in a normal piglet killed at $40 \mathrm{hr}$. The glomerular tufts and proximal tubules of the kidney of no. 5 were normal, but degenerative lesions of capricious distribution were seen in the ascending loop of Henle. These lesions, consisting of foci of pyknotic necrosis involving a number of adjacent cells, differed from the acute degenerative changes of the nephron seen most markedly in no. 27. Some very early inflammatory changes were seen in the lungs of no. 13.

\section{Sow $B$}

History and clinical observations. Nothing is known of the fate of the first litter of this sow, but the second litter (by boar I) included two piglets that were found dead on the third day without evident jaundice, and two of the living piglets had weakly sensitized cells; eight piglets were weaned. On 30 March 1953 the sow's serum titres against the boar's cells were 8 by direct agglutination and 128 by the antiglobulin test. It was reported that the sow was short of milk at this time. 
Sow B was said to have been vaccinated against swine fever in February 1952 and January 1953.

Twelve piglets (nos. 14-25) were born with manual assistance on 29 June 1953 one of which (no. 24) was stillborn. A further piglet was found on the following morning, having been born probably between 4.0 and 8.0 a.m. The sow's milk supply was observed to be failing on the day after farrowing. It was intended to restrict detailed examination to the first $48 \mathrm{hr}$. of life and to the first four healthy piglets born; the whole litter was removed from the sow, when blood samples were taken, to minimize unequal opportunities for feeding.

Apart from the stillbirth, five piglets were dead by the end of the fourth day (nos. 16, 19, 21, 23 and 26). The remaining piglets survived, their feeds being supplemented with cow's milk from the fifth day. The clinical manifestations of the piglets were those of acute malnutrition, particularly marked hypothermia, bradycardia and hypoglycaemic convulsions; in addition, at autopsy the stomach of piglet 19, for example, was ballooned and almost empty. The likelihood that the death of the piglets was due to malnutrition rather than as a result of the haemolytic process is supported by the haemoglobin and blood sugar findings (Table 2). Nevertheless, no. 14 was obviously anaemic and nos. 16,19 and 21 were pale.

Table 2

\begin{tabular}{|c|c|c|c|c|}
\hline \multirow[b]{2}{*}{ Piglet no. } & \multicolumn{2}{|c|}{ Blood sugar, mg./100 ml. } & \multicolumn{2}{|c|}{$\mathrm{Hb}$ in g. \% } \\
\hline & $42 \mathrm{hr}$. & $67 \mathrm{hr}$. & $42 \mathrm{hr}$. & $67 \mathrm{hr}$. \\
\hline 14 & 94 & 80 & $5 \cdot 8$ & $5 \cdot 9$ \\
\hline 15 & — & 92 & $8 \cdot 8$ & - \\
\hline 16 & $37 *$ & Dead & $7 \cdot 7$ & Deac \\
\hline 17 & 57 & 74 & $7 \cdot 9$ & $8 \cdot 3$ \\
\hline 18 & 70 & 78 & - & $9 \cdot 6$ \\
\hline 19 & 48 & 9 & - & $7 \cdot 0$ \\
\hline 20 & 78 & 95 & - & $8 \cdot 2$ \\
\hline 21 & 30 & Dead & - & Deac \\
\hline 22 & 57 & 69 & - & $11 \cdot 8$ \\
\hline 23 & 41 & Dead & - & Deac \\
\hline 26 & 40 & Dead & - & Deac \\
\hline
\end{tabular}

Serological findings. As in the previous farrowing, the sow's serum titres against the boar's cells did not alter significantly before, during and after parturition, being about 16 by direct agglutination and 256 by the indirect antiglobulin test. The milk titres similarly remained fairly constant during and just after the farrowing, and seemed uninfluenced by the administration of pituitrin to relieve the sow's agalactia. The agglutinin titre of the milk was generally about one tube lower than that of the serum, and the indirect antiglobulin titre of the milk about one tube higher.

The direct antiglobulin test on samples of cord blood from all piglets, except no. 26, from which no sample was obtained as its birth was not observed, were negative. Samples from the first four piglets were tested again on the day of birth, and it was shown that the cells of nos. 14 and 15 were strongly sensitized 
after 8 and $7 \mathrm{hr}$. of suckling respectively and those of nos. 16 and 17 were weakly but definitely sensitized after 6 and $5 \mathrm{hr}$. suckling. By between 23 and $30 \mathrm{hr}$. after suckling the cells of nos. 14-23 were strongly sensitized. At the same time the sera of piglets nos. 14-17 were examined for free antibody by the indirect antiglobulin test, using the cells of boar I; only the sample from no. 15 was positive, the titre being 2 . The cells of nos. 25 and 26 were examined about $23 \mathrm{hr}$. and $10-15 \mathrm{hr}$. after

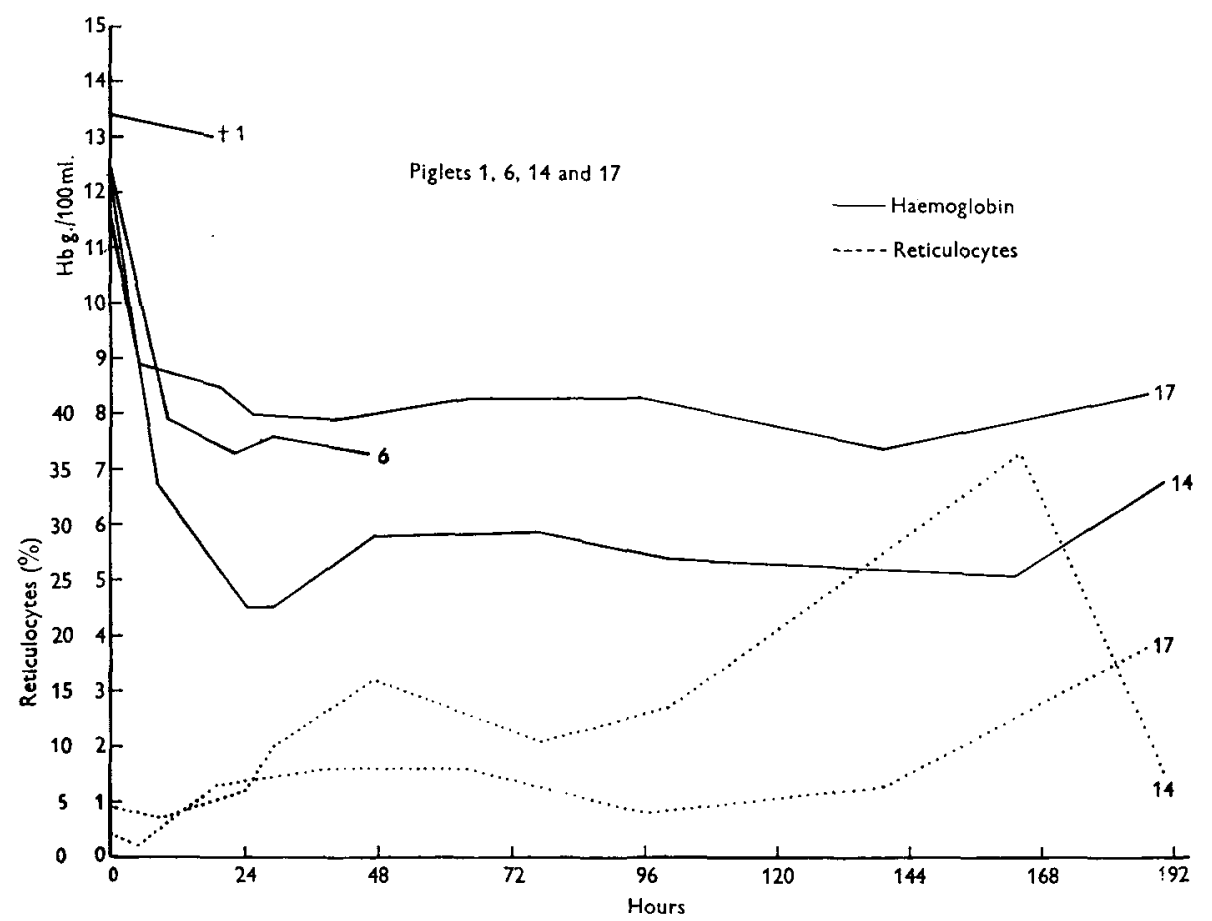

Fig. 1.

birth respectively; the cells of no. 25 were only weakly sensitized and those of no. 26 were not sensitized. It should be mentioned that though no. 26 was seen searching for milk it was never seen to suckle, and by this time there may have been very little milk available from the sow.

Haematological findings. Serial observations were made on three piglets (nos. 14, 15 and 17). The fall of haemoglobin concentration in the first $12-24 \mathrm{hr}$. by about a third in nos. 15 and 17 is similar to that observed in the first litter. In no. 14, however, the haemoglobin level was reduced by three-fifths (to $4.5 \mathrm{~g} . / 100 \mathrm{ml}$.) in the first $\mathbf{2 4} \mathrm{hr}$. and the animal was clinically anaemic. This piglet was born first, and had $1 \frac{1}{2} \mathrm{hr}$. opportunity for feeding without competition and proved to be a very greedy piglet during the period of observation. The haemoglobin and reticulocyte readings of nos. 14 and 17 , together with the haemoglobin readings of two piglets of sow A's litter (nos. 1 and 6) are given in Fig. 1. Some haemoglobin levels are recorded in Table 2.

Biochemical findings. Some blood sugar estimations for the second and third days are given in Table 2. 


\section{Sow C}

History and clinical observations. The three litters of this sow were by boar I. The first litter comprised seven piglets successfully reared, and the eleven piglets of the second litter were said all to have been jaundiced and to have died within 4 days of birth. It was reported that the sow had been vaccinated against swine fever in February 1952.

The sow farrowed unexpectedly on 14 July 1953. The animal was last seen without piglets at 1.0 p.m. and by 4.10 p.m. five piglets had been born, two of them very recently. Neither the time of birth, nor the birth order of the piglets could be assessed accurately; the birth time was assumed to be 3.0 p.m. for any calculations, and the animals were arbitrarily numbered 27-31. After blood samples had been taken these piglets were returned to the sow, and since they may have suckled before being seen they were studied thereafter as cases of haemolytic disease.

Eight more piglets were born, three of which were stillborn (nos. 36-38). The five live-born piglets (nos. 32, 33, 34, 35 and 39) were for comparison with the first five piglets (nos. 27-31) fed artificially with cow's milk. Two of them (nos. 33 and 34) were not returned to the sow at any time, and the other three were allowed to suckle at $19 \mathrm{hr}$. (nos. 32 and 39) and $25 \mathrm{hr}$. (no. 35). Of the five piglets left suckling the sow, two were killed for histological investigation (no. 29 at $13 \frac{1}{2} \mathrm{hr}$, and no. 31 at $25 \frac{1}{2} \mathrm{hr}$. when it was already moribund). The remaining three piglets were closely observed clinically. Slight pallor was detectable in no. 27 at about $20 \mathrm{hr}$. when its haemoglobin level was $6.5 \mathrm{~g}$. and, also at $20 \mathrm{hr}$., no. 28 was very pale when its haemoglobin was $2.9 \mathrm{~g}$; ; this time both animals were quite active. By $24 \mathrm{hr}$. some weakness was evident, and it was thought that no. 30 was slightly icteric (haemoglobin $2.6 \mathrm{~g}$.); at this time these animals were having to compete for food with the more vigorous control animals which by now had been returned to the sow. By $3 \mathrm{l} \mathrm{hr}$. no. 30 was moribund and no. 28 was weak and slightly jaundiced (haemoglobin $2 \cdot 4$ g.). At $40 \mathrm{hr}$. no. 28 was very pale, very weak and slightly icteric (haemoglobin 1.2 g.), but no. 27 , in whom the symptoms were developing more slowly, was at this time quite active though pale, and jaundice was only just apparent (haemoglobin $2.8 \mathrm{~g}$.). No. 28 died at about $43 \mathrm{hr}$. and at $50 \mathrm{hr}$. no. 27 was weak but could stand, very pale and slightly jaundiced (haemoglobin $1.4 \mathrm{~g}$.); this animal died about $64 \mathrm{hr}$. after birth.

The piglets that were artificially fed received warmed cow's milk liberally and $20 \mathrm{ml}$. of $20 \%$ glucose-saline subcutaneously, all 4-hourly. By $18 \mathrm{hr}$. of age these piglets were scouring and the glucose was discontinued. When the piglets were returned to the sow they did not take much interest in the sow's milk. At $24 \mathrm{hr}$. there was some scouring in the piglets that had remained on the sow throughout the experiment, and it seemed likely that some of the young animals were suffering an intercurrent infection. One of the piglets (no. 39) survived for a considerable period, being strong and having a good pink colour, but the other four died during the third day probably of infection leading to hypoglycaemia.

Serological findings. The experience in previous litters was confirmed regarding 
the stability of serum titres in the sow in the ante-natal period. The direct agglutination titre remained at 64 with minor fluctuations both before and shortly after farrowing and the indirect antiglobulin test gave similar results at the level of 2048. The colostrum titres at farrowing were slightly higher by direct agglutination and considerably higher $(16,000)$ by the antiglobulin test than the serum samples. By the third day after farrowing no agglutinating antibody was detectable in the milk, and the incomplete antibody in the milk, as estimated by the antiglobulin test, had fallen to 256 .

The direct antiglobulin test was applied as soon as possible to the cord blood samples of the five piglets that were born unobserved (tested between 4.47 and 4.59 p.m.). Only one was positive (that from no. 29) suggesting not only that it was likely to have been the first-born but also that since it could not have been born longer than $3 \frac{1}{2} \mathrm{hr}$., this time was adequate for the passage of ingested antibody through the gut. The indirect antiglobulin test was applied to these piglets' sera about $4 \mathrm{hr}$. after birth and already substantial amounts of antibody were present, the titres being 128 for no. 27 and greater than 256 for the other four.

The remaining eight piglets (including the three stillbirths) were found to have unsensitized cells, and the cells of the five that lived continued to be unsensitized for the rest of the experiment. Three of these animals, however, had opportunities for suckling: nos. 32 and 39 at $19 \mathrm{hr}$. when returned to the sow and no. 35 likewise at $25 \mathrm{hr}$. Though nos. 32 and 35 were not at first seen to suckle they were force-fed half an ounce of sow's milk (with a titre greater than 4000 at this time) piglet 39 was also given one ounce of sow's milk but it was seen to suckle, though not vigorously, about $30 \mathrm{hr}$. after birth. The cells of these five piglets (nos. 32-35 and 39) were shown to be incompatible with the sow's serum.

Haematological findings. The clinical history of this sow and the high serum antibody titres led us to expect severe cases of haemolytic disease. Our observations on the piglets of sows A and B showed that blood destruction was greatest in the first 18-24 hr. of life. Accordingly samples were taken 3-hourly for the first $48 \mathrm{hr}$. after birth and 6- to 7-hourly thereafter until death, from three affected piglets (nos. 27, 28 and 30); no. 39, a control animal reared on cow's milk, was studied fairly fully. In addition, reticulocyte counts and nucleated cell counts were undertaken.

The haemoglobin levels are plotted in Fig. 2. A rapid fall during the first $24 \mathrm{hr}$. was again observed in the affected animals, whereas no. 39, whose cells were never sensitized, exhibited only mild fluctuations in haemoglobin level. But an unexpected phenomenon was observed in all three sets of data on the affected piglets, namely, a brief but striking rise of haemoglobin concentration about $12 \mathrm{hr}$. after birth which interrupted the steep overall drop in haemoglobin observed during this $24 \mathrm{hr}$. period. At the same time a moderate reticulocytosis corresponding with this phenomenon was observed, being $12 \%$ in nos. 28 and 30 and $5 \%$ in no. 27 which was less severely affected. No. 28 lived just sufficiently long to develop another reticulocytosis of $22 \%, 4 \mathrm{hr}$. before death and no. 27 at the same time had a response of $44 \%$ followed on the third day by a response of $51 \%$ about $8 \mathrm{hr}$. before death. The erythroblastaemic pattern was similar. Anisocytosis and poly- 
chromasia were marked in the severely affected animals. None of these abnormalities was observed in the control piglet, no. 39.

Biochemical findings. Blood sugar estimations were made on some of the samples from the affected animals, but the artificially fed control animals were included

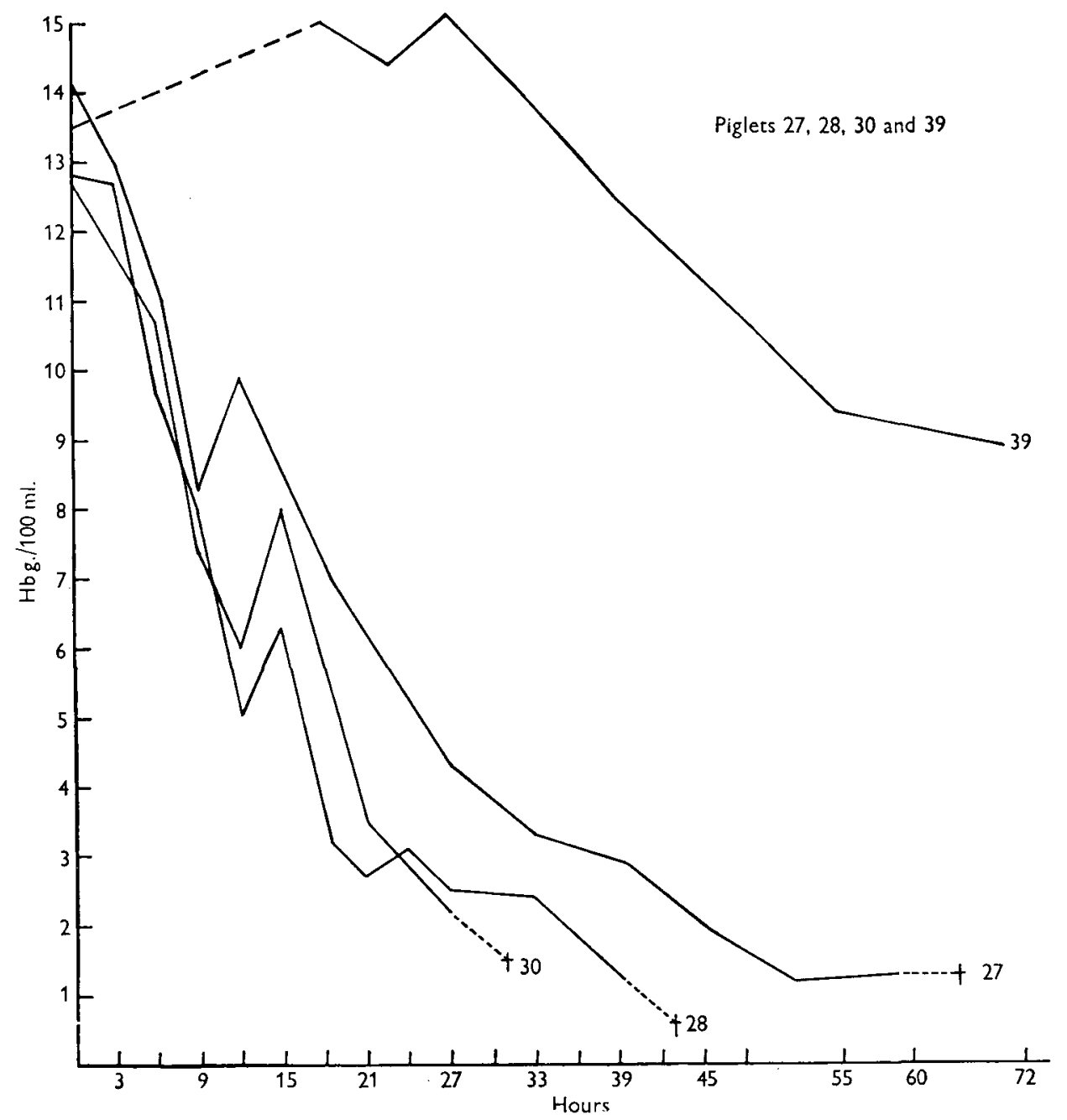

Fig. 2.

only from the third day (Table 3). Three serum samples from no. 27 between 12 and $20 \mathrm{hr}$. after birth were examined for bilirubin content, and the results showed a rise from 1.3 to $1.8 \mathrm{mg}$. $/ 100 \mathrm{ml}$. The bilirubin level of no. 39 at $20 \mathrm{hr}$. was $0.8 \mathrm{mg}$.

Morbid anatomical and histological findings. At post-mortem examination the viscera were slightly jaundiced in the more severely affected animals. There was marked congestion of the liver, spleen and kidneys and these organs appeared to be slightly enlarged. The bladder urine was straw-coloured in nos. 28 and 29 , but was tinged with red in nos. 27 and 30. Apart from pallor, no significant abnormality was 
detected in the gross specimens of the other organs. The principal microscopic findings were as follows:

Liver. Foci of haemorrhagic necrosis in the centrilobular- and mid-zones of the lobules were evident, no. 28 showing the most extensive lesions. Considerable sinusoidal distension was also noticeable particularly in Susa-fixed material. The Kupffer cells were prominent and displayed considerable erythrophagocytosis especially in the necrotic lesions. The liver cells showed considerable glycogen vacuolation, and proliferation of liver cells was moderate. Extramedullary haemopoiesis was within normal limits and was not abnormally erythropoietic. Haemosiderin and bile-pigment deposits were evident in the liver cells, and in the case of haemosiderin in the Kupffer cells; these appearances were less marked in nos. 30 and 31 than in the others. Fat was present in small amounts only. Bile plugs were occasionally seen in the canaliculi.

Table 3

Blood sugar, mg./100 ml.

\begin{tabular}{|c|c|c|c|c|c|}
\hline Piglet no. & $21 \mathrm{hr}$. & $33 \mathrm{hr}$. & $45 \mathrm{hr}$. & $52 \mathrm{hr}$. & $\begin{array}{r}61 \mathrm{hr} . \\
32^{*}\end{array}$ \\
\hline $\begin{array}{l}27 \\
28\end{array}$ & $\begin{array}{l}68 \\
26\end{array}$ & $\begin{array}{r}122 \\
27\end{array}$ & $\begin{array}{c}78 \\
\text { Deadt }\end{array}$ & 59 & $\begin{array}{l}32 * \\
-\end{array}$ \\
\hline 30 & 27 & Dead $\dagger$ & - & - & - \\
\hline 32 & - & - & 29 & $8 \ddagger$ & Dead \\
\hline 39 & - & $\longrightarrow$ & 60 & 61 & 52 \\
\hline & \multicolumn{5}{|c|}{$\begin{array}{l}\text { * Approx. } 6 \mathrm{hr} \text {. before death. } \\
\text { † Less than } 2 \mathrm{hr} \text {. before sample due. } \\
+ \text { Approx. } 1 \mathrm{hr} \text {. before death. } \\
\text { - = no sample. }\end{array}$} \\
\hline
\end{tabular}

Spleen. The pulp was engorged in the more severe cases. Focal haemorrhages were apparent, together with a variable reduction in the lymphocytic cuffing of the arterioles. Erythrophagocytosis was marked. Haemosiderin was apparent in the more severely affected cases. Haemopoiesis was not marked and was predominantly myelopoietic. Piglet no. 27 showed the most marked changes and no. 29 the least.

Kidney. The most severe lesions were seen in no. 27. The glomerular tufts were abnormal. The endothelial cells were swollen and the capsular space distended with closely-packed particles of slaty-blue hyaline material. The tubules were the seat of widespread damage which, however, spared the basement membrane. Nuclear pyknosis and hyaline droplet degeneration were marked in the proximal convoluted tubules and were seen in lesser degree in the distal tubules and loops of Henle. Granular and hyaline casts, often pigmented, were evident and they tended to become more eosinophilic with passage through the lower nephron. There was no evidence of regeneration of tubular epithelium.

Oedema was marked, especially in the medulla. Some phagocytosis was evident in the cortex but no extramedullary haemopoiesis was seen in the kidney. Considerable deposits of dark-brown granular pigment were seen in the convoluted tubules, and moderate amounts of haemosiderin principally in the cortex. 
Piglet no. 28 exhibited similar lesions which, for the most part, were less severe. However, there was evidence of early fatty change in the surviving convoluted tubules. Another feature in this animal was focal haemorrhage in the outer half of the sub-foetal zone of the cortex together with congestion in this area; these haemorrhages were distinct from those normally found in the superficial parts of the cortex in young piglets.

Piglet no. 29 showed only very minor changes from the normal, and there was very little pigment. Some fatty degeneration was seen in the distal convoluted tubules and extramedullary haemopoiesis was quite marked, more so than in any other piglet in the series.

The lesions in no. 30 were similar to those of nos. 27 and 28 , but much less severe. Some casts in the collecting tubules appeared to be composed of material similar to that seen in the capsular spaces. In no. 31 the lesions were also mild but widespread. Traces of haemosiderin were seen in a few tubules particularly associated with the brush border of the proximal tubules.

Lung. There was marked erythrophagocytosis by macrophages in the alveolar walls in nos. 27-30. Some oedema was evident, and areas of partial collapse were surrounded by areas of compensatory emphysema. Pigment deposits were scanty. A very mild focal inflammatory response was visible in no. 28. The lungs in nos. 32 and 33 showed confluent bronchopneumonia.

Apart from widespread deposits of finely granular pigment, no noteworthy features were observed in the other tissues sectioned: adrenal, thyroid, lymph glands and brain. There were no brain lesions resembling kernicterus in man.

\section{Sow $D$}

History and clinical observations. This sow was said to have raised three previous litters, the first two of which, comprising eleven and four piglets, were reared successfully. The third litter of fourteen piglets was observed and described by Buxton \& Brooksbank as suffering from haemolytic disease of the newborn. The sow was said to have been vaccinated against swine fever in January 1952; and it had been served by boar I for the fourth litter only.

Six piglets were born in Cambridge on 24 October 1953 (nos. 4l-46) of which no. 41 was weak at birth and did not at first suckle well; it was not the subject of any special experiment though it was observed clinically and examined serologically. The small size of the litter caused us to modify our plans and restrict our observations to a few points only. Two piglets (in addition to the weakling no. 41) were left to suckle the sow and were studied in detail haematologically (nos. 43 and 45). The three remaining piglets (nos. 42, 44 and 46) were not permitted to suckle at first but were sustained by 2-hourly injections of $5 \mathrm{ml}$. of glucose-saline, receiving no nourishment by mouth; they were returned to the sow at 4,8 and $12 \mathrm{hr}$. after birth respectively. The animals all survived the neonatal period.

There was no diminution of activity in any of the piglets during this experiment. Very slight pallor was first seen in no. 43 when it was examined $12 \mathrm{hr}$. after birth (the haemoglobin level being then $8.0 \mathrm{~g}$.), and at $26 \mathrm{hr}$. the pallor was rather more obvious and evident also in no. 45; at the same time a slight creaminess was seen in 
these animals. At $50 \mathrm{hr}$. the pallor was more marked, being now present also in no. 41 , and the icterus was nearly at its peak being greatest in no. 41 , less marked in nos. 43 and 45 , mild in no. 42 and barely visible in nos. 44 and 46 . The icterus seemed rather less obvious in the whole litter at $74 \mathrm{hr}$., and at $98 \mathrm{hr}$., when the pallor had stopped increasing, there was a definite decline in the degree of icterus. Jaundice had almost completely disappeared from all the animals by 7 days. The daily weights of the animals are recorded in Table 4.

Table 4

\begin{tabular}{|c|c|c|c|c|c|c|c|c|}
\hline $\begin{array}{l}\text { Piglet } \\
\text { no. }\end{array}$ & $\begin{array}{l}\text { Birth } \\
\text { lb. oz. }\end{array}$ & $\begin{array}{l}50 \mathrm{hr} . \\
\text { lb. oz. }\end{array}$ & $\begin{array}{l}74 \mathrm{hr} . \\
\text { Ib. oz. }\end{array}$ & $\begin{array}{l}98 \mathrm{hr} . \\
\text { lb. oz. }\end{array}$ & $\begin{array}{l}\text { 7th day } \\
\text { lb. oz. }\end{array}$ & $\begin{array}{l}\text { 10th day } \\
\text { lb. oz. }\end{array}$ & $\begin{array}{l}\text { 13th day } \\
\text { lb. oz. }\end{array}$ & $\begin{array}{c}\text { 18th day } \\
\text { lb. oz. }\end{array}$ \\
\hline 41 & 3 & 2 & 1 & $\begin{array}{ll}3 & 2\end{array}$ & 3 & $\begin{array}{lll}5 & 10\end{array}$ & 6 & 8 \\
\hline 42 & 4 & 415 & 6 & $\begin{array}{ll}5 & 14\end{array}$ & 2 & $\begin{array}{ll}9 & 8\end{array}$ & 13 & 15 \\
\hline 43 & 4 & 410 & 410 & $\begin{array}{ll}5 & 1\end{array}$ & $\begin{array}{ll}5 & 14\end{array}$ & 8 & 12 & $14 \quad 13$ \\
\hline 44 & 4 & 415 & $\begin{array}{ll}5 & 9\end{array}$ & 6 & $\begin{array}{ll}7 & 9\end{array}$ & 10 & 14 & $17 \quad 3$ \\
\hline 45 & 4 & 412 & 0 & 5 & $\begin{array}{ll}6 & 12\end{array}$ & 9 & 11 & 1311 \\
\hline 46 & 3 & 4 & 8 & 411 & 5 & 7 & 1013 & 12 \\
\hline
\end{tabular}

Serological findings. The serum titre of sow D against boar I's cells at farrowing was 2048 in both the direct agglutination test and the indirect antiglobulin test; the titre of the milk, by the indirect test both at farrowing and for the first 2 days after farrowing, varied between 8000 and 32,000. Cord blood samples of all piglets proved negative when tested with antiglobulin serum. The cells of the three piglets left on the sow became sensitized after suckling; each piglet kept off the sow was tested before its return, when the test was negative and again after suckling when the cells were shown to be sensitized. The piglets' cells from the cord blood were agglutinated by dilutions of the sow's milk, the titres being 256 in some cases and 1024 in others; the same samples tested by the indirect antiglobulin reaction showed the titre of the incomplete form of the antibody to be 4096 in each case. The piglets' sera were titrated against cord blood samples of their own cells and the cells of boar I to ascertain the amount of free antibody present in their sera (Table 5).

\section{Table 5}

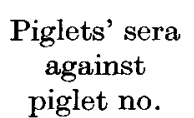

41

42

43

44

45

46
Cord blood samples of their own cells

$\begin{array}{ccc}26 \mathrm{hr} . & 35 \mathrm{hr} . & 50 \mathrm{hr} . \\ 512 & 512 & 128 \\ 512 & 2 & - \\ 512 & 512 & 8-16 \\ 32 & \text { No sample } & - \\ 512 & 512 & 128 \\ 128 & 8 & -\end{array}$

Cells of boar I

\begin{tabular}{ccc}
\hline $50 \mathrm{hr}$. & $74 \mathrm{hr}$. & $98 \mathrm{hr}$ \\
512 & 32 or 64 & 32 \\
8 or 16 & 8 or 32 & 32 \\
512 & 512 & 512 \\
256 or 512 & 256 or 512 & No sample \\
512 & 128 or 256 & 32 or 64 \\
512 & 512 & 512
\end{tabular}

Haematological findings. The haemoglobin levels of all the piglets were estimated at fairly infrequent intervals and the results are given in Table 6 . The levels had fallen to less than half the birth value in $24 \mathrm{hr}$., and to about a quarter in $48 \mathrm{hr}$. in those animals that were left to suckle the sow freely. The differences particularly 
in the early stages between these animals (nos. 41, 43 and 45) and those that were returned to the sow a little later (nos. 42, 44 and 46) are apparent from the table.

Two piglets (nos. 43 and 45 ) were studied in detail for the first $18 \mathrm{hr}$. The same rapid fall of haemoglobin was observed, together with the haemoglobin 'spike'. The haemoglobin, reticulocyte and normoblast levels of no. 43 are plotted in Fig. 3,

Table 6

Haemoglobin in g. \%

\begin{tabular}{|c|c|c|c|c|c|c|c|c|c|}
\hline $\begin{array}{c}\text { Piglet } \\
\text { no. }\end{array}$ & Birth & $26 \mathrm{hr}$. & $35 \mathrm{hr}$. & $50 \mathrm{hr}$. & $63 \mathrm{hr}$. & $74 \mathrm{hr}$. & $98 \mathrm{hr}$. & $\begin{array}{l}\text { 10th } \\
\text { day }\end{array}$ & $\begin{array}{l}\text { 13th } \\
\text { day }\end{array}$ \\
\hline 41 & $\ldots$ & $6 \cdot 2$ & $5 \cdot 5$ & $4 \cdot 2$ & $3 \cdot 9$ & $4 \cdot 2$ & 4.5 & 4.9 & $4 \cdot 3$ \\
\hline 43 & $14 \cdot 5$ & $6 \cdot 1$ & $5 \cdot 7$ & $3 \cdot 2$ & $3 \cdot 3$ & $3 \cdot 8$ & $3 \cdot 3$ & $6 \cdot 4$ & $7 \cdot 7$ \\
\hline 45 & 14.7 & $5 \cdot 3$ & $5 \cdot 4$ & $4 \cdot 3$ & $5 \cdot 2$ & $3 \cdot 9$ & $3 \cdot 7$ & $4 \cdot 7$ & $4 \cdot 6$ \\
\hline 42 & - & $8 \cdot 0$ & $7 \cdot 3$ & $6 \cdot 0$ & - & $5 \cdot 1$ & $5 \cdot 3$ & $4 \cdot 5$ & $4 \cdot 2$ \\
\hline 44 & - & $8 \cdot 1$ & 一 & $7 \cdot 1$ & - & $4 \cdot 6$ & - & $7 \cdot 1$ & $7 \cdot 4$ \\
\hline 46 & - & $9 \cdot 2$ & $8 \cdot 3$ & $5 \cdot 2$ & - & $3 \cdot 9$ & $3 \cdot 7$ & $5 \cdot 9$ & $6 \cdot 7$ \\
\hline
\end{tabular}

together with those of no. 27 from the former litter for comparison. The graph shows the fall of haemoglobin concentration of no. 43 for the first $40 \mathrm{hr}$. of life; at $48 \mathrm{hr}$. the level was $3 \cdot 3 \mathrm{~g}$. and it remained at about this level for a further 2 days (Table 6). The normoblast estimations in Fig. 3 are expressed as percentages. Total nucleated counts of $17,000-20,000$ per $\mathrm{mm}^{3}$ seem to be the rule in the newborn piglet, except in cord blood samples in which, in our experience, the count is always less than 10,000 per $\mathrm{mm} .^{3}$. In no. 43 the normoblasts represented between 6 and $28 \%$ of the total nucleated cell count during the period of study.

Biochemical findings. The blood sugar and bilirubin values are given in Table 7.

Table 7

\begin{tabular}{|c|c|c|c|c|c|c|c|c|c|}
\hline \multirow{3}{*}{$\begin{array}{l}\text { Piglet } \\
\text { no. }\end{array}$} & \multicolumn{3}{|c|}{$\begin{array}{l}\text { Blood sugar, } \\
\text { mg./100 ml. }\end{array}$} & \multicolumn{6}{|c|}{ Serum bilirubin, $\mathrm{mg} . / 100 \mathrm{ml}$. } \\
\hline & & & & & & & & 9 th & 12th \\
\hline & $50 \mathrm{hr}$. & $74 \mathrm{hr}$. & $98 \mathrm{hr}$. & $26 \mathrm{hr}$. & $50 \mathrm{hr}$. & $74 \mathrm{hr}$ & $98 \mathrm{hr}$. & day & day \\
\hline 41 & 62 & 81 & 99 & - & - & - & - & - & - \\
\hline 42 & 108 & 104 & 114 & - & - & 一 & - & - & - \\
\hline 43 & 90 & 106 & 104 & - & $1 \cdot 3$ & $2 \cdot 3$ & 0.2 & $0 \cdot 2$ & Nil \\
\hline 44 & 92 & 102 & - & 一 & 一 & 一 & 一 & - & - \\
\hline 45 & 87 & 104 & 100 & 1.0 & 1.8 & $1 \cdot 1$ & 0.5 & $0 \cdot 3$ & Nil \\
\hline 46 & 94 & 87 & 93 & - & - & - & - & - & - \\
\hline
\end{tabular}

\section{DISCUSSION}

The four litters described seemed to us to display four degrees of severity of neonatal haemolytic disease. The litter of sow A displayed no evidence of clinical disease, and would probably have been considered normal had not some of the animals suffered by comparison with their litter-mates from nutritional disadvantages consequent upon frequent laboratory tests. But their cells were sensitized so they must be considered as suffering from haemolytic disease. Such mild disorder would not be detectable in the field. The litter of sow B, though more 
seriously affected if the haemoglobin levels are considered, showed few clinical features that could be ascribed to haemolytic disease except for the pallor of no. 14, and to a lesser extent of nos. 16, 19 and 21. The litter of sow D showed a more severe form of the condition in which pallor and icterus were noteworthy, and the clinical features in this litter were not complicated by fortuitous factors leading to

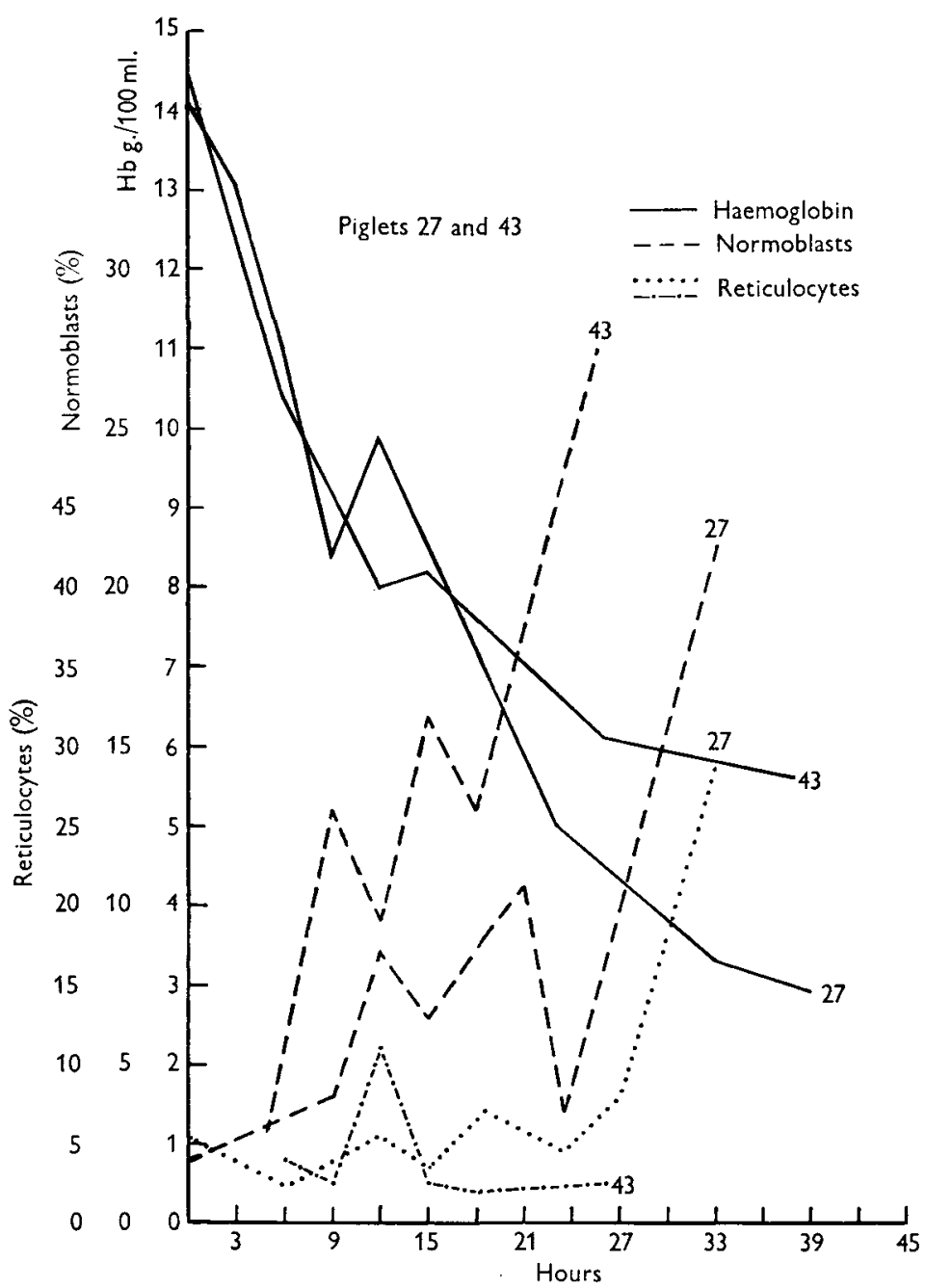

Fig. 3.

malnutrition soon after birth which confused the observations on the litters of sows $A$ and B. But sow D's litter all survived the neonatal period, whereas in that of sow $C$, the most severe of those we saw, the affected animals (nos. 27, 28 and 30) died of haemolytic disease after showing marked pallor, icterus and extreme lassitude.

In some other published reports (Bruner et al. 1949; Doll \& Brown, 1954) death took place more quickly than in any of our cases, which were comparable in 
severity with some of those reported by Szent Iványi \& Szabó (1953) and Buxton \& Brooksbank $(1953 a, b)$. The severity of the condition in our litters accorded very generally with the titres of incomplete antibody in the colostrum at the time of farrowing, being about 128 and 512 in sows $\mathrm{A}$ and $\mathrm{B}$, and about 16,000 in sows $\mathrm{C}$ and D.

The severity of the condition does not appear to correlate absolutely with the minimal haemoglobin level. Indeed, it is astonishing how active newborn piglets may remain with haemoglobin levels of $3 \mathrm{~g}$. or less. Table 5 shows that no. 43, which recovered, sustained a haemoglobin level between 3.2 and $3.8 \mathrm{~g}$. for at least 3 days. The surprising activity of the piglets during profound anaemia is doubtless another factor that causes this condition to be overlooked in the field. During the time the haemoglobin is low the piglets, though sustaining life, may exhibit jaundice and marked pallor. Death appears to correlate rather with the speed of fall of haemoglobin. In this matter the longer life of no. 27 compares with nos. 28 and 30, the speed of haemoglobin fall differing (Fig. 2); and these animals may be compared for the same factors with no. 43 (Fig. 3). We have referred elsewhere (Goodwin, Hayward, Heard \& Roberts, 1955) to a piglet, not in this series, that recovered after the haemoglobin had fallen to as little as $2 \cdot 1 \mathrm{~g}$. at $96 \mathrm{hr}$. after birth, but at $72 \mathrm{hr}$. the haemoglobin was $3 \cdot 6 \mathrm{~g}$. In our experience a piglet survives if its haemoglobin level does not fall below about $3 \mathrm{~g}$. by $72 \mathrm{hr}$. after birth; a possible explanation for this will be mentioned later. Clinically pallor is usually detectable when the haemoglobin has fallen to about $7 \mathrm{~g}$., though with experience it is possible to estimate the haemoglobin concentration over a very wide range accurately to within 1 or $2 \mathrm{~g}$. by inspecting the colour of the animal's skin. Weakness is not usually evident until the haemoglobin falls below about $4 \mathrm{~g}$.

Malnutrition was apparent in several of the piglets studied, particularly in the litter of sow B whose milk supply failed early. It is clear, however, that malnutrition contributes significantly to the morbid condition in haemolytic disease. Ingestion of milk containing a powerful antibody might exert its effects either by provoking a mortal haemolytic anaemia or by inducing such lassitude that the animal dies of starvation through inability to suckle. On the other hand, since the sugar reserves of the newborn piglet soon become depleted, it may be that milk containing an antibody of low titre might be beneficial to the animal. An example of the former circumstances may be taken from sow D's litter; nos. 43 and 45 gained weight more slowly than nos. 42 and 44, for, though they had better opportunities for feeding, they ingested more of the high titre antibody and had greater falls of haemoglobin (Tables 4 and 6). An example of the latter circumstances is provided by sow A's litter, in which nos. 10 and 12 had better opportunities to ingest milk containing low titre antibody than had nos. 2 and 3, and were notably heavier on the fifth day (Table 1).

Jaundice has not been a feature in previously published cases of this disease in piglets, except those of Buxton \& Brooksbank $(1953 a, b)$ in which it was generally observed by $48 \mathrm{hr}$. after birth. Jaundice was evident, though never very marked, in the more severely affected cases in this series. It was detectable as early as $24 \mathrm{hr}$. in no. 30 and $26 \mathrm{hr}$. in no. 41 , but it was seen rather later $(40 \mathrm{hr}$.) in no. 27 , 
in which the disease moved more slowly. In no. 27 the bilirubin level was $1.8 \mathrm{mg}$. at $20 \mathrm{hr}$., before icterus was evident; the readings also appeared low in other animals, for example, no. 43 was only slightly icteric and never provided a level higher than $2.3 \mathrm{mg}$. (Table 7 ). By about 5 days after birth the bilirubin levels were very low again and jaundice had passed off by about 8 days. With these figures it is not surprising that jaundice was slight. However, the bilirubinaemia and jaundice do not seem to match in severity the acute process of blood destruction that precedes them, and in our view this matter merits further attention. It may be of interest that bilirubin is normally absent from the serum of the adult pig. It should be mentioned that the mild jaundice in newborn piglets that we observed was manifested by a creamy rather than a golden colour, and varied with the alignment of the inspecting eye relative to the lie of the skin hairs; the golden colour is more evident at autopsy. We did not seek pigments other than bilirubin in the serum.

The serological evidence showed that only minor fluctuations could be expected in serum antibody titres during the ante-natal period, but there was insufficient evidence to show when, if at all, the milk titres might fall post-partem to enable the piglets to be returned to the sow safely. In general, the antibody titre in the colostrum was higher than that in the serum. The higher titres by the indirect antiglobulin test compared with the agglutination test, particularly in the samples from sow C, may reasonably suggest the presence of an incomplete form of antibody.

Our results supported the contention that the pig's placenta is impermeable to blood group antibodies. It was more difficult to reach conclusions about the permeability to antibody molecules of the newborn piglets' intestinal mucosa. It seemed that antibody absorption is rapid, at any rate immediately after birth; the piglets' red cells may become sensitized as early as $3 \frac{1}{2} \mathrm{hr}$. after birth (no. 29), and by $4 \mathrm{hr}$. antibody titres of at least 256 were demonstrated in the piglets serum (nos. 28-31), these titres presumably taking no account of the antibody already absorbed on to the cells. It was also established that the agglutinating form of antibody may pass the gut and may agglutinate the piglets' cells. No certain evidence was obtained, however, about the period elapsing after birth until antibody is no longer able to pass into the circulation from the gut: if, indeed, this time is constant. Antibody was clearly able to pass into the circulation after $12 \mathrm{hr}$., at any rate in a piglet that had received nothing by mouth since birth (no. 46). Rather more doubt arises at $19 \mathrm{hr}$. after birth when nos. 32 and 39 were first returned to the sow; they were both force-fed a small quantity of high titre milk at this time (and were seen to suckle later), but in neither piglet were the cells sensitized though no. 32 was tested $30 \mathrm{hr}$. later and no. 39 frequently tested in the ensuing days. However, these animals may not have taken any milk naturally from the sow on their return until at least $30 \mathrm{hr}$. after birth, and so little weight can be attached to this evidence.

The relatively high titres of free antibody demonstrated in the piglets' sera within a few hours of suckling were noteworthy and would account not only for the rapid destruction of red cells but for the haemoglobin level remaining low 
until the declining titre indicated that less antibody was available for the cells (e.g. no. 45 in Tables 5 and 6). Some of the evidence in Table 5 is not easy to interpret. The sustained titres of nos. 43 and 46 in the second half of the table in which the cells of boar I were used for testing, despite the falling antibody titre against their own cells, may indicate that these piglets inherited only some of the boar's incompatible antigens. But the generally lower and more rapidly declining titres from those animals that were not at first put to suck (nos. 42, 44 and 46 in the first part of the table) are consistent with their having absorbed less antibody. It was evident that several red cell antigen-antibody systems were concerned in these litters, and it was remarkable that newborn piglets absorbing relatively high-titre antibody $(8000-32,000)$ showed so little clinical disability and made a complete recovery (sow D's litter).

The haematological investigations, particularly the red and white cell counts and to a lesser extent the reticulocyte estimations, were beset with technical difficulties that were not fully resolved until the latter part of our study. For this reason only those figures that are reliable are published. The principal feature of these results is a marked fall of haemoglobin during the first $24 \mathrm{hr}$., followed by reticulocytosis and by erythroblastaemia. This fall of haemoglobin appears to have three components. The initial fall during the first $12 \mathrm{hr}$. seems to be at much the same rate, regardless of the severity of the condition, and this is followed by a brief but sharp rise in haemoglobin (which we call the 'spike') at 12-15 hr. accompanied by a reticulocyte response. The final component consists of a further sharp fall, the rate of which depends upon the severity of the condition; if the animal lives long enough there is also a further reticulocytosis together with erythroblastaemia. The significance of these observations cannot be assessed without more data, but it is tempting to suggest that the initial fall is due to the destruction of red cells due to the action of ingested antibody and that the 'spike' represents an intermission brought about either by the production of more red cells on account of the anaemia or by sudden supplementation from some store. The rate of further fall of haemoglobin could then be ascribed to the amount of the free antibody remaining in the piglets' circulation. If, then, the continuing reticulocytosis represents an increasing rate of production of new red cells balancing the loss from diminishing haemolysis, the low but stable haemoglobin during the third and fourth days in piglets that are to recover (e.g. no. 43) may be accounted for. These observations suggest that the danger of death from anaemia is greatest during the first $48 \mathrm{hr}$, but that thereafter the principal risk is of malnutrition consequent upon the weakness causing inability to feed. Indeed the newborn piglet seems better able to rely upon its reserve of red blood cells than upon its reserves of sugar.

The histological observations would have benefited from comparison with a large number of normal piglets studied at different ages. We were able to avail ourselves of only three normal piglets killed at 2,18 and $40 \mathrm{hr}$., apart from several animals in this series that had not been permitted to suck. In the severely affected animals the principal changes were foci of mid-zonal or centrilobular haemorrhagic necrosis in the liver, and degeneration and necros s in the kidney sometimes 
affecting the entire nephron. In addition, deposits of haemosiderin and other pigmented derivatives of haemoglobin were widespread in most of the organs studied and erythrophagocytosis was marked particularly in the lung. It appeared that these changes were more fully developed in the animals that lived longest. In piglet no. 27, which lived for $64 \mathrm{hr}$., the renal and hepatic lesions were marked; there was little fatty change. Piglet no. 28, which lived for $43 \mathrm{hr}$., showed severe hepatic changes with very slight evidence of glycogen vacuolation. Piglet no. 29, on the other hand, which was killed at $13 \frac{1}{2} \mathrm{hr}$., showed less necrosis in the kidney and liver and more fatty change; glycogen vacuolation was more evident and pigment deposits were less marked. The changes in the spleen and lung were minimal in this animal, though by haematological standards it was perhaps the most severely affected. Piglet no. 29 showed lesions intermediate in severity between those of nos. 27 and 29 in all organs except the liver and its length of life was also intermediate. Erythrophagocytosis, however, was marked in all the animals. It is remarkable that no evidence of extramedullary erythropoiesis was found in any of the animals, though in the absence of bone marrow studies, the importance of this finding cannot be assessed.

In the pig, unlike man and the rabbit, antibody does not appear to reach the foetus in utero. This is one of the features that makes us doubt whether any syndromes comparable with hydrops foetalis and kernicterus in man are to be found in the piglet. After birth, however, large quantities of antibody may be ingested and can reach the piglets' red cells within a few hours, so that in severe cases a sudden and rapidly developing haemolytic anaemia may kill the animal before any regeneration of red cells is possible. In less severely affected cases the anaemia, profound though it is, may be tolerated so that the survival of the animal may depend upon its retaining sufficient activity to nourish itself until more red cells are formed and the antibody excreted. The remarkable ability of the piglet to remain active and relatively symptom-free during an anaemia that would be regarded as extremely severe by human standards accounts not only for this disease being commonly overlooked in the field but also for the low mortality of a condition that may very well have quite a high incidence.

Though the evidence suggests that this disease is manifest in the newborn piglet as an acute haemolytic anaemia which follows artificial immunization we believe that, for ease of reference, the condition is most conveniently described as haemolytic disease of the newborn piglet.

\section{SUMMARY}

Four litters of newborn piglets suffering from haemolytic disease of four different grades of severity, were observed clinically. Pallor and mild jaundice were evident in some cases, but the activity of the piglets was not reduced except in the terminal stages of fatal cases. Malnutrition affected a number of piglets sometimes from fortuitous factors. In mild cases there were no clinical symptoms, and the disease could be detected only by demonstrating a fall in haemoglobin level or sensitization of the red cells. 
Several blood group systems were concerned in the genesis of the disease in these piglets and both agglutinating and incomplete antibodies were shown to be present in the piglets' circulations; in one case antibody was found in the piglet's circulation only $3 \frac{1}{2} \mathrm{hr}$. after suckling started, and by $4 \mathrm{hr}$. the titre of free antibody was 256 . The antibodies did not pass the placenta.

In severe cases a rapid fall in haemoglobin, interrupted by a sharp, transient rise, and accompanied by reticulocytosis and erythroblastaemia, was characteristic of the first $24 \mathrm{hr}$; ; this was followed in some cases by a prolonged low level of haemoglobin before recovery started.

In some of the animals that died, severe and widespread focal necrosis of the liver, together with degeneration and necrosis in the kidney, were marked. Pigment deposits and erythrophagocytosis were common in nearly all organs but abnormal extramedullary erythropoiesis was not observed.

A number of haematological, serological and biochemical findings are recorded.

During the preparation of this paper, Dr B. H. G. Hayward died suddenly. The histological observations are taken from his incompletely prepared notes and may well not do justice to his views after examining and considering a large amount of material. We are most grateful to Messrs J. C. Buxton and N. H. Brooksbank for supplying us with the sows, and to Prof. L. P. Pugh for fostering this work. Other valuable help has been received at different stages from Dr R. R. A. Coombs, Dr B. M. Herbertson and Miss R. Saison, while Mr P. J. D. V. Brett has assisted in the general handling of the animals. This work was carried out with the assistance of a grant from the Agricultural Research Council.

In comformity with recent recommendation we have used the verb 'to suckle' to indicate an activity of the young.

\section{REFERENCES}

Bruner, D. W., Brown, R. G., Hull, F. E. \& Kinkaid, A. S. (1949). Blood factors and baby pig anemia. J. Amer. vet. med. Ass. 115, 94.

Buxton, J. C. \& Brooksbank, N. H. (1953a). Haemolytic disease of new-born pigs caused by iso-immunisation of pregnancy. Vet. Rec. 65, 287.

Buxton, J. C. \& Brooksbank, N. H. (1953b). Haemolytic disease of new-born pigs caused by iso-immunization of pregnancy. Nature, Lond., 172, 355.

Doll, E. R. \& Brown, R. G. (1954). Isohemolytic disease of newborn pigs. Cornell Vet. 44, 86.

Doll, E. R., Richards, M. G., Wallace, M. E. \& Bryans, J. T. (1952). The influence of an equine fetal tissue vaccine upon hemagglutination activity of mare serums: its relation to hemolytic icterus of newborn foals. Cornell Vet. 42, 495.

Goodwin, R. F. W., Hayward, B. H. G., Heard, D. H. \& Roberts, G. Fulton (1955). Acquired haemolytic anaemia occurring in newborn piglets. Sang, 26, 24.

Goodwin, R. F. W., Saison, R. \& Coombs, R. R. A. (1955). The blood groups of the pig. II. Red cell iso-antibodies in the sera of pigs injected with crystal violet swine fever vaccine. J. comp. Path. 65, 79.

Patterson, J., Swale, J. \& Maggs, C. (1952). The estimation of serum bilirubin. Biochem. J. $52,100$.

SoмоgYi, M. (1945). A new reagent for the determination of sugars. J. biol. Chem. 160, 61 .

Szent Iványi, T. \& Szabó, S. (1953). Untersuchungen über die Ursache der hämolytischen Gelbsucht der neugeborenen Ferkel. Acta vet. hung. 3, 75. 